\title{
Studies of impact on fluvial ecosystems by airborne remote sensing: thermal discharges in river Tajo and suspended solids diffusion in rivers Esera and Cinca (Spain)
}

\author{
R. Peña, M.L. Serrano, A. Ruiz-Verdú \\ Centro de Estudios y Experimentación de Obras Públicas (CEDEX), Paseo Bajo de la Virgen del Puerto, 3 \\ 28005 Madrid, España.
}

\begin{abstract}
The two main objectives of this work, carried out by CEDEX were to study thermal pollution in River Tajo and to analyse diffusion suspended solids in rivers Esera and Cinca (river Ebro basin). Work was carried out in 1994, 1995,1996 and 1997 using INTA's Daedalus 1268 (ATM), multispectral scanner, selecting a nominal pixel size of $3.5 \mathrm{~m}$ at nadir. Results obtained show the viability of using airborne remote sensing to analyse water quality of Spanish rivers, usually not sufficiently wide to be studied with satellite imagery.
\end{abstract}

Key words: Water quality, thermal discharges, suspended solids, airborne remote sensing.

\section{RESUMEN}

El CEDEX ha realizado dos estudios sobre la calidad del agua utilizando sensores remotos aeroportados. Los dos objetivos principales de estos trabajos han sido el estudio de la contaminación térmica del río Tajo y el análisis de la difusión de sólidos en suspensión en los ríos Ésera y Cinca (Cuenca del Ebro). Los estudios se llevaron a cabo en 1994,19951996 y 1997 utilizando el Daedalus 1268 del INTA (ATM) un sensor multicanal con una selección de cuadrícula de 3.5 m en el nadir. Los resultados obtenidos muestran la viabilidad de los sensores remotos aerotransportados para el análisis de la calidad del agua de los ríos españoles, generalmente demasiado estrechos para ser estudiados mediante imágenes satelitales.

Palabras clave: calidad del agua, descargas térmicas, sólidos en suspensión, sensores remotos aerotransportados

\section{INTRODUCTION}

During the last few years, the "Centro de Estudios Hidrográficos" of CEDEX has been monitoring water quality in reservoirs, by both conventional methods and by remote sensing, with the main aim of evaluating trophic levels, (Ortiz \& Peña, 1989; Peña \& Serrano, 1992, 1994). The TM-5 Landsat sensor, with a spatial resolution of $30 \mathrm{~m}$, is considered to be adequate for studying reservoirs. Application of remote sensing to the analysis of impacts on rivers, on the other hand, has used imagery taken by airborne sensors, since their resolution is much higher than satellite images. Resolution of airborne-sensor images may vary from $7 \mathrm{~m}$ to $1.7 \mathrm{~m}$, depending on flight altitude. Numerous surveys have used airborne sensors to estimate water quality parameters. (Melack \& Gastil, 1992; Fraser, 1998; Cracknell, 1999). These studies show the usefulness of airborne sensor imagery to represent with great detail the spatial distribution of certain optical active components (i.e. OAC) of waterbodies (mainly chlorophyll $a$, suspended solids and dis- 
solved organic matter), an area better alternative to conventional interpolation approaches. The limitations in the accuracy of airbone-sensor imagery are associated with interference in the spectral signatures of different $\mathrm{OAC}_{\mathrm{s}}$. The use of hyperspectral sensors (e.g. CASI, AVIRIS) with a lot of narrow channels reduces this effect, although data analyse become more complex. The main limitation to an extensive use of airborne remote sensing, however, is related to economic cost. A summary of airborne remote sensing systems can be found in Danson and Plummer (1995) and in Tarusov et al. (1996).

Two cases are presented in this paper evaluating different impacts on fluvial ecosystems and monitoring their changes in subsequent years.

The first case consists of the analysis of the impact produced by cooling water discharge into River Tajo, either directly or through a reservoir, by the main nuclear and fossil fuel power plants located in its basin (Almaraz, Trillo, Zorita and Aceca). The study and impact assessment was performed during the summers of 1994, 1995 and 1996. The main objective was to estimate the temperature rise pattern in the river resulting from cooling-water discharge at very high temperature. The size of the area potentially impacted was also

Table 1. Field campaigns for the study of thermal discharges. Tabled are areas, dates, and number of sampling sites. An asterisk indicates a night flight. $N P=$ nuclear power plant, $F P=$ fossil fuel power plant. Campañas de muestreo para el estudio de las descargas térmicas: áreas, fechas y número de puntos de muestreo. El asterisco después de la fecha indica un vuelo de noche.

\begin{tabular}{lccc}
\hline Zone & Type & Date & n \\
\hline Aceca & FP & $94 / 07 / 21$ & 7 \\
& & $94 / 07 / 21 *$ & 7 \\
Almaraz & & $95 / 07 / 21$ & 7 \\
& NP & $94 / 07 / 19$ & 9 \\
Trillo & & $94 / 07 / 21 *$ & 9 \\
& & $95 / 06 / 13$ & 9 \\
Zorita & NP & $94 / 06 / 19$ & 9 \\
& & $94 / 06 / 13$ & 9 \\
Zorita (Almoguera) & NP & $95 / 06 / 13$ & 13 \\
& & $95 / 06 / 21$ & 15 \\
& & $96 / 06 / 20$ & 15 \\
& & $96 / 06 / 20$ & 9 \\
\hline
\end{tabular}

assessed influence. In addition, the study allowed evaluation of the impact caused by water temperature changes on other parameters, such as chlorophyll and suspended solids concentration.

The second case looked at impacts produced in rivers Esera and Cinca by suspended solids downstream of the Barasona reservoir(also called Joaquin Costa reservoir). These rivers were affected by three successive emptying operations during the period 1995-1997, needed to repair the bottom gates of the dam. Large amounts of suspended solids were brought downstream. This survey was performed in three different campaigns. Flights were scheduled before and after each emptying operation during autumn, 1995, 1996 and 1997. Suspended solids concentration and water temperature were the main variables followed in surveys.

\section{MATERIAL AND METHODOLOGY}

\section{a. Study of thermal discharges}

Areas for data collection covering upstream and downstream regions from each plant were first identified (Fig. 1). Dates, areas of field campaigns and number of sampling sites (n) are shown in Table 1.

At Zorita nuclear plant, two flying paths were established in the 1996 survey. One covered the stretch upstream of the water intake, used for cooling. The second covered the Almoguera reservoir, downstream from the plant.

On flight dates, simultaneous on-site sampling campaigns ( \pm 1 hour) were performed measuring water temperature, chlorophyll $a$ and suspended solids concentration.

\section{b. Study of suspended solids diffusion in Rivers Esera and Cinca}

Six flying paths, were defined corresponding to four fluvial stretches between Barasona reservoir and the junction of river Cinca with the river 
Segre, (Fig. 2). The areas surveyed are the following:

Area 1 - Fraga. This area covers confluence of rivers Cinca and Segre, including the urban area of Fraga.

Area 2 - Ballobar. It is located upstream from Area 1, between the villages of Chalamera and Albalate.

Area 3 - Monzón. This area covers River Cinca upstream and downstream from the urban area of Monzón

Area 4 - Barasona. This includes river Esera, from the dam of Barasona reservoir to its junction with River Cinca .

Area 5 - Segre. It was defined to cover river Segre down to the town Mequinenza. Data are available for this area only for the last date. Area 6 - Mequinenza. This area includes the junction of rivers Segre and Ebro at Ribarroja reservoir.

Field samples were taken in order to determine suspended solids concentration and water surface temperature on seven dates during the period 1995-1997 (i.e. 95/09/27, 95/10/16, 95/11/28, 96/09/25, 96/10/10, 97/09/30, 97/10/0).

Images were provided by INTA (i.e. National Aerospace Institute; Instituto Nacional de Técnica Aeroespacial). The multispectral sensor used was the ATM DAEDAULS 1268, installed in a CASA modified aircraft. This sensor can provide eleven spectral bands of surface-reflected radiation, from blue to thermal infrared wavelength. More resolute images can be achieved by flying at lower altitudes.

A pixel resolution of $3.5 \mathrm{~m}$ was selected for these studies. This resolution is much higher than that provided by the TM-5 sensor of the Landsat satellite (i.e. $30 \mathrm{~m}$ ).

Images were processed prior to elaboration of thematic maps, as follows.

\section{Data processing}

Suspended solids and chlorophyll concentration maps were prepared using linear multiple regres- sions of imagery digital numbers (DN), against field valves of suspended solids and chlorophyll concentration (Verdin, 1984). Spectral ATM bands used in equations were bands $2(0.45-0.52 \mathrm{~mm}), 3$ (0.52-0.60 mm), 5 (0.63-0.69 mm), 7 (0.76-0.90 $\mathrm{mm})$ and $9(1.55-1.75 \mathrm{~mm})$. These bands correspond to blue, green, red, and near and medium infrared spectral windows, respectively.

To convert digital numbers from the thermal infrared band 12 (8.5-13 $\mathrm{mm})$ to temperature values, the calibration line for the thermal sensor was used. This line was drawned by measuring the inflight response of the sensor (DN) to two black bodies at known temperatures (i.e. $5^{\circ} \mathrm{C}$ and $45^{\circ} \mathrm{C}$ ). The equation obtained has the general form:

$t=D N($ band 12$) * m+n$

were " $t$ " is the apparent water surface temperature, " $m$ " is the line slope, and $n$ is the Y-intercept while the value of " $m$ " was remarkably constant across flights (i.e. m@0.18) “ $n$ ” was dependent on atmospheric conditions. Thus, this parameter had to be corrected for ground-level conditions. This was achieved through regression analysis between apparent temperatures estimated from equation 1 and field measurements of temperature.

Detailed mapping methods are described in Serrano \& Peña (1997).

\section{RESULTS AND DISCUSSION}

\section{a. Study of thermal discharges}

Regressions obtained for chlorophyll $a$ and suspended solids had determination coefficients (i.e. $\mathrm{r}^{2}$ ) higher than 0.7 except in the following cases:

1. Aceca chlorophyll equation, June $13^{\text {th }} 1995$. $\left(r^{2}=0.65\right)$.

2. Almaraz suspended solids equation, June $13^{\text {th }}$ 1995. $\left(r^{2}=0.53\right)$.

3. Zorita suspended solids equation, June $21 \mathrm{st}$ 1995. $\left(r^{2}=0.66\right)$.

Thematic maps (Fig. 3) suggest a great influ- 
ence of thermal discharges on River Tajo. In Trillo nuclear plant, the rise in river temperature measured on the was negligible two study dates.

In Almaraz nuclear plant, daytime temperature rose by up to $4{ }^{\circ} \mathrm{C}$ in the discharge area.

At night, temperature increases reached $7{ }^{\circ} \mathrm{C}$. This diel difference is because the river is usually colder at night. In 1995, temperature rose a maximum of $8^{\circ} \mathrm{C}$ to $9^{\circ} \mathrm{C}$.

In Aceca fossil fuel plant, the maximum temperature increase, was $5^{\circ} \mathrm{C}$ in daytime and $7^{\circ} \mathrm{C}$ at night 1994. In this plant, there were also daynight temperature differences. Increases in 1995 were of up to $6^{\circ} \mathrm{C}$.

In José Cabrera nuclear plant, at Zorita de los Canes, the maximum increase was $7^{\circ} \mathrm{C}$ to $8^{\circ} \mathrm{C}$ in 1995 and $3^{\circ} \mathrm{C}$ to $4^{\circ} \mathrm{C}$ in 1996.

In all cases, increases concerned not only the discharge area and downstream, but also the upstream area. The impact on primary production (i.e. increase in chlorophyll- $a$ concentration) and on suspended solids was not significant and probably independent of thermal discharge. In Aceca fossil fuel plant, however, the temperature rise apparently resulted in an increase of both chlorophyll- $a$ and suspended solids concentrations, as shown in images for 1994 and 1995 (Fig. 3).

\section{b. Study of suspended solids diffusion in Rivers Esera and Cinca}

The equations obtained are described in Table 2. Highest correlations between primery production parameters and digital numbers often occur with bands 3 (green) and 5 (red). These results agree with previous studies, and show a high positive correlation between suspended solids concentration and visible and nearinfrared reflectance (Ferrier, 1995; Lodhi et al., 1998). Correlations with blue wavelenghts are generally weaker, according to these studies. Thus, band 2 (blue) may have appeared in equations as a result of the Stepwise procedure of regression analysis used, because the sequence of introduction of independent variables will influence selection of subsequent variables entering the model. In all cases where band 2 was introduced in the equation, similarly high correlation were found with bands 3 and 5. Moreover, as shown in Novo et al. (1989) and Choubey (1998), spectral response of suspended solids strongly dependent on sediment type as well as on the viewing geometry. As a consequence, are the same spectral region cannot be used for all situations, by contrast, chlorophyll- $a$ can safety use a given region consistently, in most cases.

Equations provided the basis for mapping.

Table 2. Equations for suspended solids in Rivers Esera and Cinca. Areas are 1-Fraga, 2-Ballobar, 3-Monzón, 4-Barasona, 5-Segre, 6Mequinenza. Ecuaciones para los sólidos en suspensión de los ríos Ésera y Cinca. Áreas: 1-Fraga, 2-Ballobar, 3-Monzón, 4-Barasona, 5-Segre, 6-Mequinenza.

\begin{tabular}{|c|c|c|c|c|}
\hline Date & Area & Equation & $\mathbf{n}$ & $\mathbf{r}^{2}$ \\
\hline $95 / 09 / 27$ & $1,2,3,4$ & $\begin{array}{l}{[\mathrm{ss}]=72.05-2.16 * \mathrm{~B} 2} \\
+2.57 * \mathrm{~B} 5-0.82 * \mathrm{~B} 9\end{array}$ & 22 & 0.67 \\
\hline $95 / 10 / 16$ & $1,2,3,4$ & $\begin{array}{l}{[\mathrm{ss}]=371.48 * \mathrm{~B} 3} \\
-1218.66\end{array}$ & 22 & 0.76 \\
\hline $95 / 11 / 28$ & $1,3,4$ & $\begin{array}{l}{[\mathrm{ss}]=418.01 * \mathrm{~B} 2} \\
-15658.60\end{array}$ & 18 & 0.87 \\
\hline $95 / 11 / 28$ & 6 & {$[\mathrm{ss}]=7.84 * \mathrm{~B} 2-324.48$} & 8 & 0.97 \\
\hline $95 / 11 / 28$ & 7 & $\begin{array}{l}{[\mathrm{ss}]=0.51 * \mathrm{~B} 3-0.24} \\
* \mathrm{~B} 2-0.06\end{array}$ & 8 & 0.99 \\
\hline $96 / 09 / 25$ & $1,3,4$ & {$[\mathrm{ss}]=4.14 * \mathrm{~B} 2-96.04$} & 18 & 0.89 \\
\hline $96 / 09 / 25$ & 6 & {$[\mathrm{ss}]=0.60 * \mathrm{~B} 5-11.53$} & 8 & 0.83 \\
\hline $96 / 10 / 10$ & $1,3,4$ & $\begin{array}{l}{[\mathrm{ss}]=80.67 * \mathrm{~B} 3} \\
-2.57 .09\end{array}$ & 18 & 0.92 \\
\hline $96 / 10 / 10$ & 6 & $\begin{array}{l}{[\mathrm{ss}]=0.9203 * \mathrm{~B} 5} \\
-15.92\end{array}$ & 8 & 0.83 \\
\hline $97 / 09 / 30$ & $1,3,5,6$ & $\begin{array}{l}\log [\mathrm{ss}]=0.038 * \mathrm{~B} 2 \\
+0.034 * \mathrm{~B} 7-0.438\end{array}$ & 15 & 0.82 \\
\hline $97 / 09 / 30$ & 4 & {$[\mathrm{ss}]=0.248 * \mathrm{~B} 3-6.758$} & 6 & 0.71 \\
\hline $97 / 10 / 08$ & $1,3,4,5,6$ & $\begin{array}{l}\mathrm{Ln}[\mathrm{ss}]=0.045 * \mathrm{~B} 3 \\
+0.108 * \mathrm{~B} 7+0.032\end{array}$ & 24 & 0.95 \\
\hline
\end{tabular}


Barasona reservoir, made in autumn 1995, resulted in a large increase in suspended solids in River Cinca, rising from $20-100 \mathrm{mg} \cdot \mathrm{L}^{-1}$ to $5-10 \mathrm{~g} \cdot \mathrm{L}^{-1}$ and more (Fig. 4). Increases in 1996 and 1997 were not as high, reaching values of $1-4 \mathrm{~g} \cdot \mathrm{L}^{-1}$ in 1996, and around $3 \mathrm{~g} \cdot \mathrm{L}^{-1}$, in 1997 (Fig. 5). Maps obtained show that high concentrations of suspended solids found in River Cinca remain at high levels all the way downstream until the confluence with River Segre. Thereafter, concentrations decreases progressively as River Cinca flows into Ribarroja reservoir, reaching pre-emptying values. Most of solids coming from Barasona reservoir probably end up settling in this area.

\section{CONCLUSIONS}

Thematic mapping of study areas reveals the potential usefulness digital imagery obtained by airborne radiometric sensors. There type of data provide spatial resolution enabling discrimination of more specific and dynamic phenomena, such as surface flow regimes.

On the other hand, from a timing standpoint, airborne remote sensing is a very flexible technique since it allows the selection of flight dates and direct control over planning the sampling and data collection.

This can be especially useful in cloudy areas, where timing flexibility is crucial in order to be able to take neat clear images.

\section{REFERENCES}

CHOUBEY, V. K. 1998. Laboratory experiment, field and remotely sensed data analysis for the assessment of suspended solids concentration and Secchi depth of the reservoir surface water. Int. J. Remote Sensing., 19 (17): 3349-3360

CRACKNELL, A. P. 1999. Remote sensing techniques in estuaries and coastal zones - an update. Int. J. Remote Sensing., 19 (3): 485-496

DANSON, F. M. \& S. E. PLUMMER 1995. The Remote Sensing of Inland Water Quality. Advances in Environmental Remote Sensing., 8: 123-142.
DEKKER, A. G. \& M. DONZE. 1994. Imaging Spectrometry as a research tool for inland water resources analysis. In: Imaging Spectrometry - A Tool For Environmental Applications J. Hill (ed.): 295-318. Dordrecht: Kluwer Academic.

FERRIER, G. 1995. A field study of the variability in the suspended sediment concentration - reflectance relationship. Int. J. Remote Sensing, 16(14): 27132720.

FRASER, R.N. 1998. Hyperspectral remote sensing of turbidity and chlorophyll a among Nebraska Sand Hills lakes. Int. J. Remote Sensing, 19(8): 15791589.

LODHI, M. A., D. C. RUNQUIST, L. FAN, \& M. S. KUZILA. 1998. Estimation of suspended sediment concentration in water using integrated surface reflectance. Geocarto Intl. 13 (2): 11-15.

MELACK, J.M. \& M. GASTIL. 1992. Seasonal and spatial variations in phytoplanktonic chlorophyll in eutrophic Mono Lake, California, measured with the AVIRIS. Proceedings of the $3^{\text {rd }}$ Airborne Geosciences Workshop. Pasadena: JPL 92-14: 5355.

NOVO, E. M. M., J. D. HANSOM, \& P. J. CURRAN. 1989. The effect of sediment type on the relationship between reflectance and suspended sediment concentration. Int. J. Remote Sensing., 10 (7): 1283-1289

ORTIZ, J.L. \& R. PEÑA. 1989. Water quality monitoring in Spanish Reservoirs by satellite remote sensing. CEDEX, Madrid.

PEÑA, R. \& M. L. SERRANO. 1992. Evaluación del estado trófico de los embalses mediante imágenes digitales. Ingeniería Civil.86: 37-44.

PEÑA, R. \& M. L. SERRANO. 1994. Seguimiento del estado trófico de los embalses del alto Tajo por teledetección. Limnetica, 10: 69-81.

SERRANO, M.L. \& R. PEÑA. 1997. Evolución del estado trófico de tres embalses del Júcar por teledetección, In: Teledetección. Usos y Aplicaciones J.L. Casanova \& J. Sanz Justo (eds.): 223-229. Universidad de Valladolid.

TARUSSOV, A., J.-M. M. DUBOIS \& M. WENZL. 1996. Les systèmes légers de télédetection aéroportée pour les sciences de la Terre. Int. J. Remote Sensing, 17 (14): 2699-2718

VERDIN, J.P. 1984. Limnological applications of multispectral remote sensing. USBR Report No.REC-ERC-85-2. 51pp. 


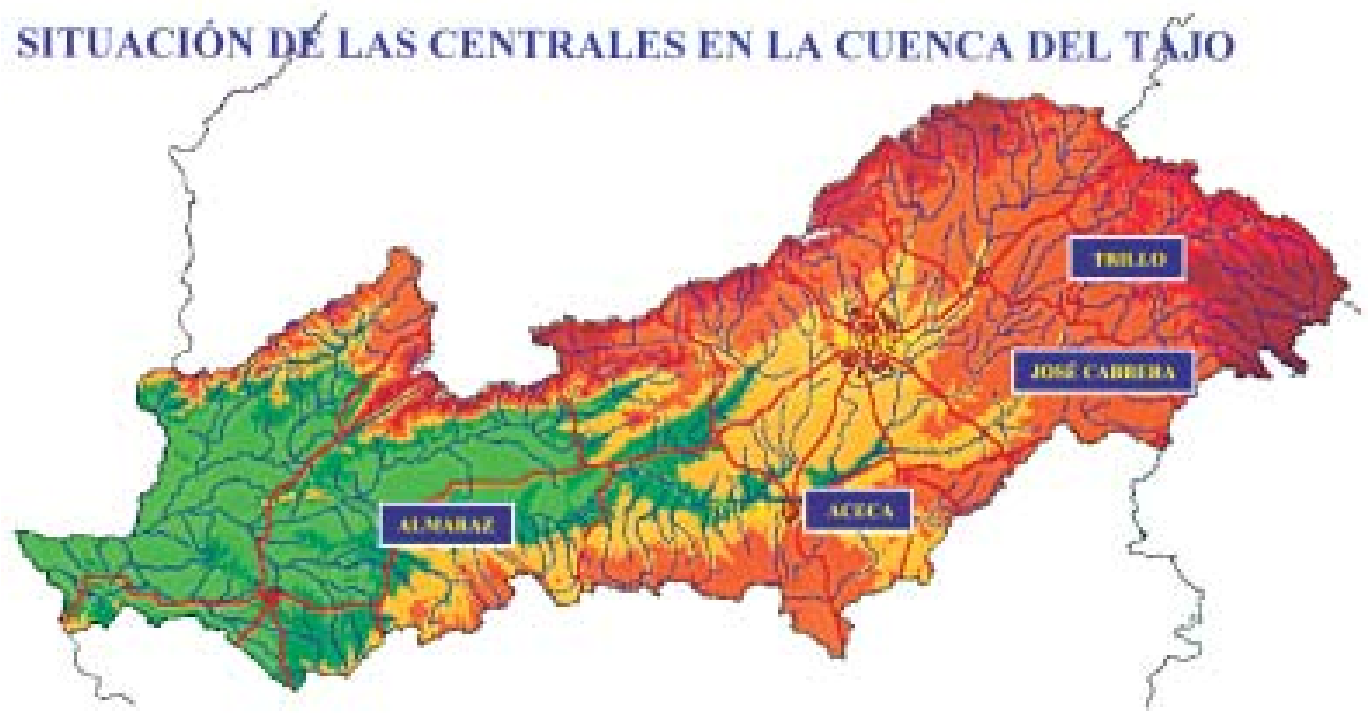

Figure 1. Study of thermal discharges. Location of plants. Estudio de las descargas térmicas: localización de las plantas.

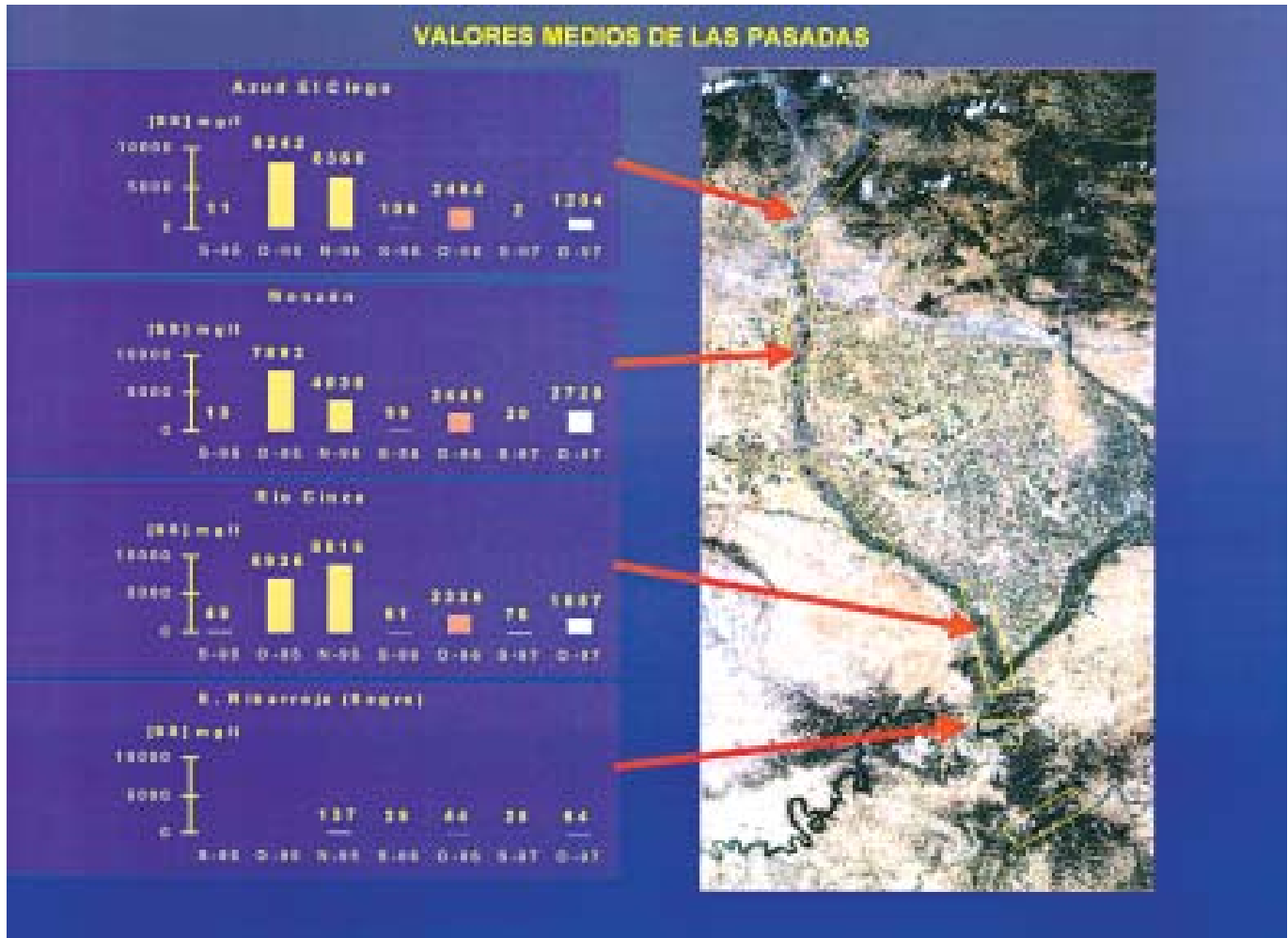

Figure 2. Study of suspended solids diffusion in Rivers Esera and Cinca. Study areas and final results. Estudio de los sólidos en suspensión en los ríos Ésera y Cinca: áreas de estudio y resultados finales. 

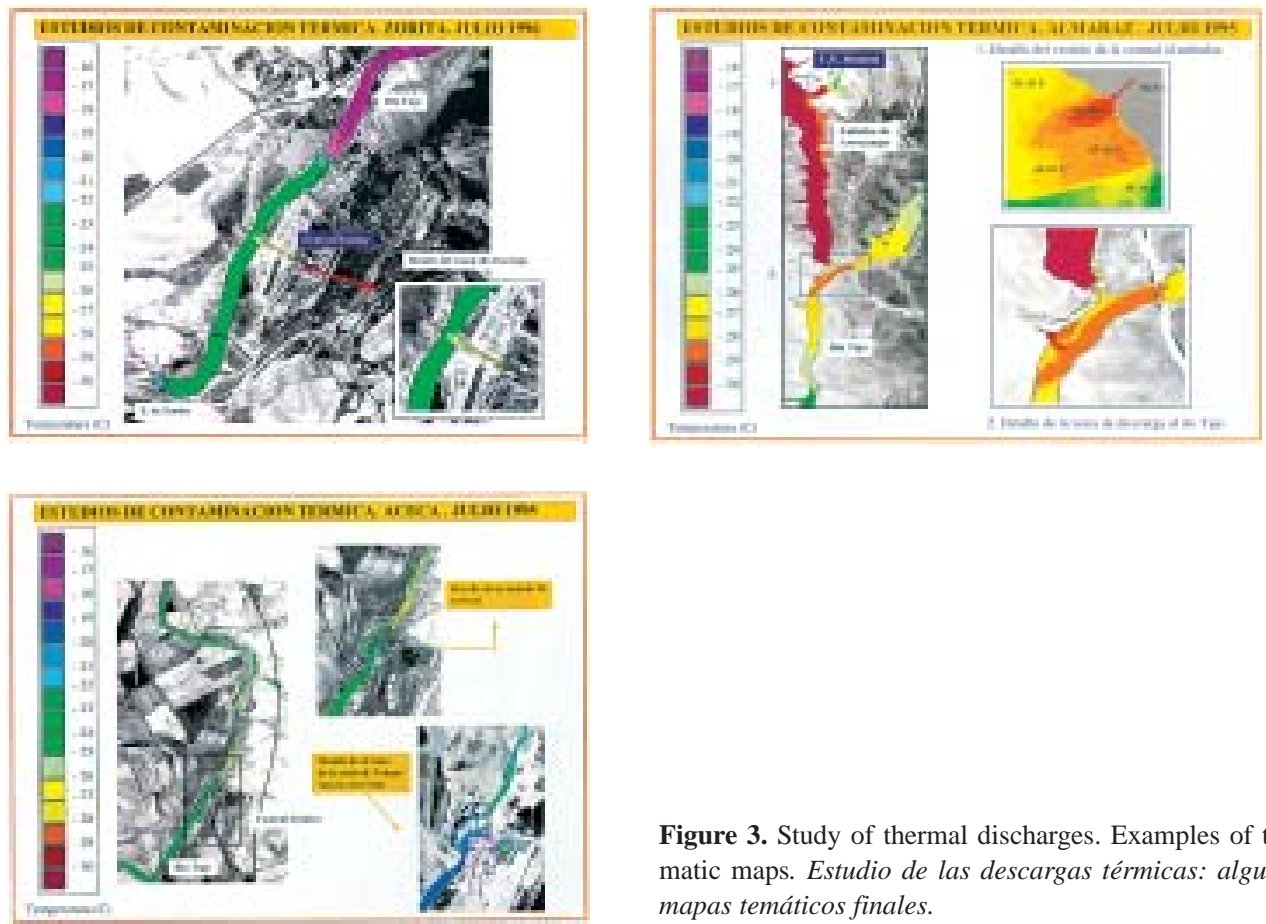

Figure 3. Study of thermal discharges. Examples of thematic maps. Estudio de las descargas térmicas: algunos mapas temáticos finales.

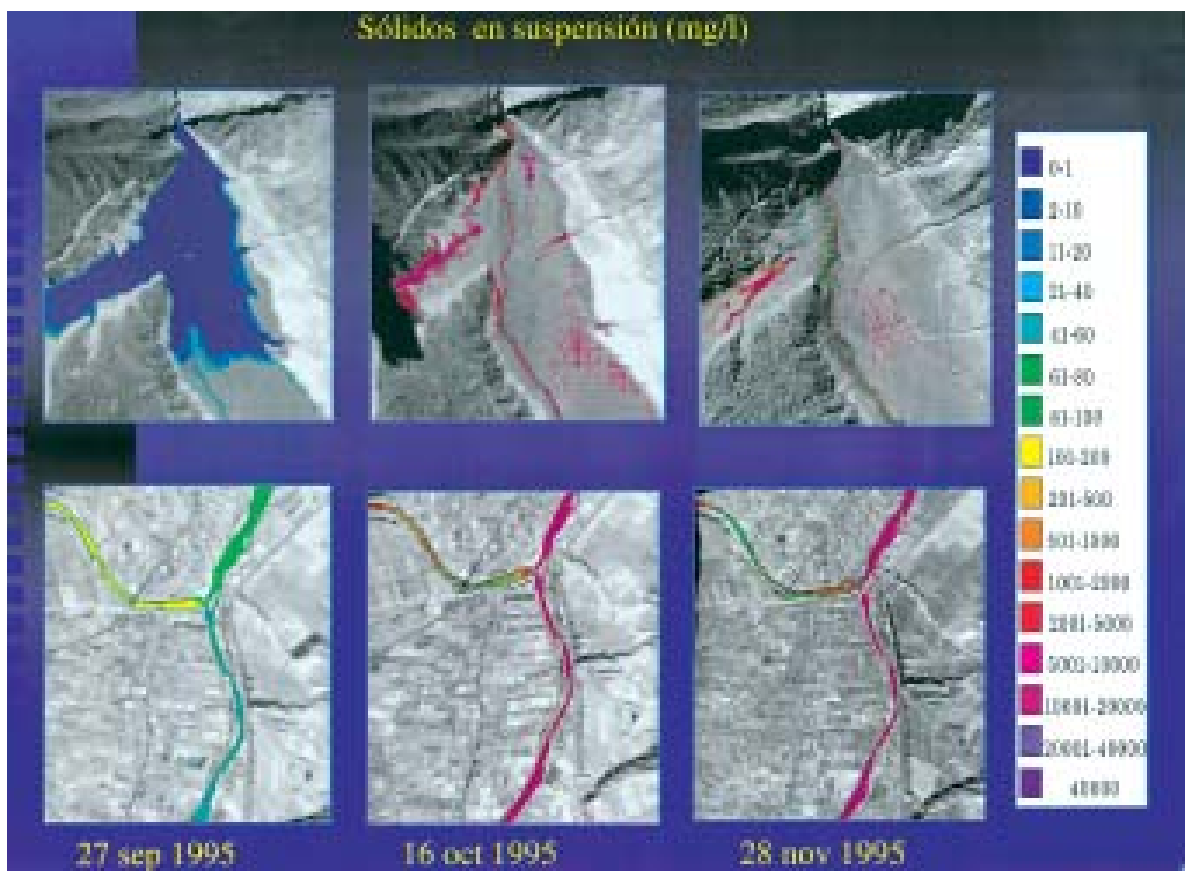

Figure 4. Study of suspended solids diffusion in Rivers Esera and Cinca. Thematic maps of the area of Barasona reservoir and the confluence of Rivers Cinca and Segre before and after the emptying of the reservoir in 1995. Estudio de la difusión de sólidos en suspensión en los ríos Ésera y Cinca: mapas temáticos del área del embalse de Barasona y la confluencia de los ríos Cinca y Segre antes y despues del vaciado de 1995. 
Sólidos en suspensión en la zona de Mequinenza después de los vaciados
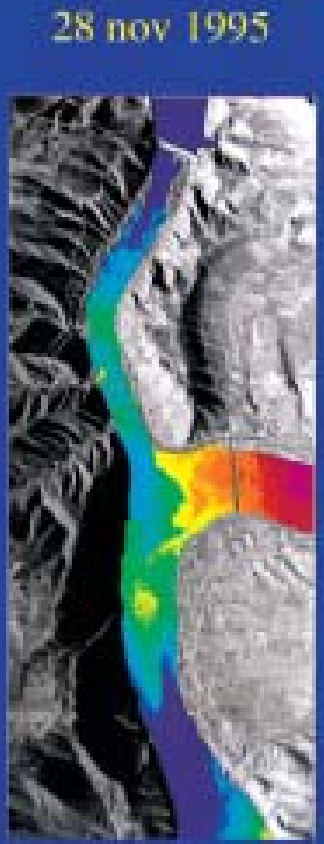

10 oct 1996

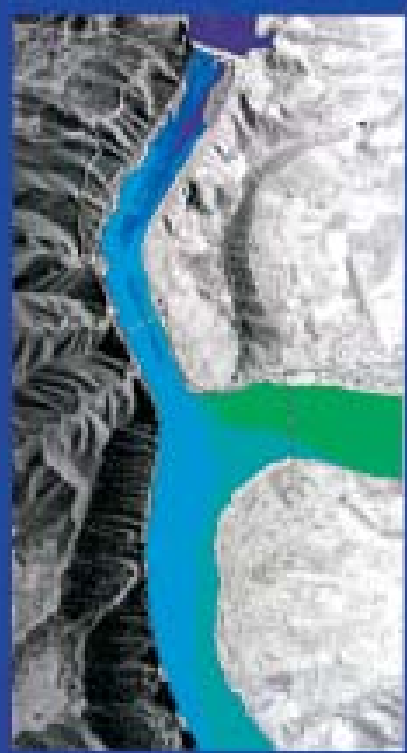

8 oct 1997

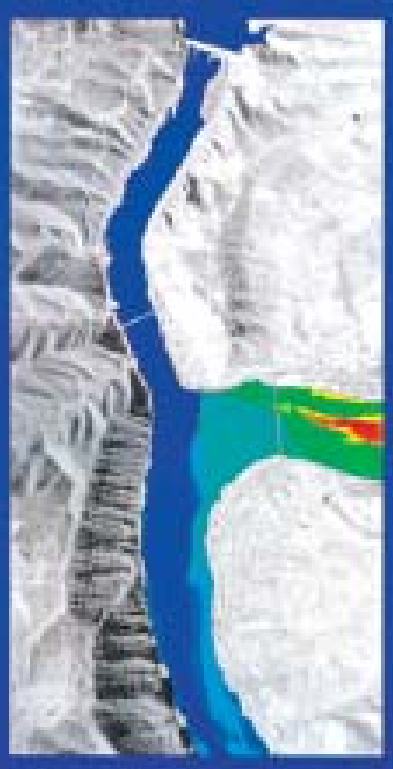

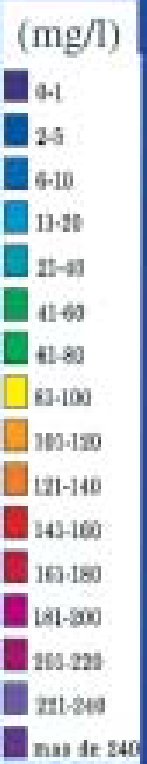

Figure 5. Study of suspended solids diffusion in Rivers Esera and Cinca: thematic maps of the area of Mequinenza reservoir after emptying. Estudio de la difusión de los sólidos en suspensión en los ríos Ésera y Cinca: mapas temáticos del área de Mequinenza después del vaciado. 